\title{
Trace element levels in foetus-mother pairs of short-beaked common dolphins (Delphinus delphis) stranded along the French coasts
}

\author{
V. Lahaye ${ }^{a}$, P. Bustamante ${ }^{a}$, W. Dabin ${ }^{b}$, C. Churlaud ${ }^{c}$ and F. Caurant ${ }^{a,{ }^{*}}$
}

\begin{abstract}
${ }^{a}$ Centre de Recherche sur les Ecosystèmes Littoraux Anthropisés, UMR 6217 CNRS-IFREMER-Université de La Rochelle, Université de La Rochelle, 22 Avenue Michel Crépeau, 17042 La Rochelle Cedex, France

${ }^{\mathrm{b}}$ Centre de Recherche sur les Mammifères Marins, Institut du Littoral et de l'Environnement, Port des Minimes, Avenue du Lazaret, 17000 La Rochelle, France

${ }^{c}$ Centre Commun d'Analyses, Université de La Rochelle, 5 Perspectives de l'Océan, 17071 La Rochelle Cedex 9, France
\end{abstract}

\section{*: Corresponding author : F. Caurant, email address : florence.caurant@univ-Ir.fr}

\begin{abstract}
:
Tissues of foetus-mother pairs of common dolphins (Delphinus delphis) stranded along the French coasts (Bay of Biscay and English Channel) were analysed for their $\mathrm{Cd}, \mathrm{Cu}, \mathrm{Hg}$, Se and $\mathrm{Zn}$ contents. In the kidneys, foetal $\mathrm{Cd}$ levels were extremely low, and strong relationships between $\mathrm{Cu}$ and $\mathrm{Zn}$ suggested the involvement of metallothioneins since early foetal life. The results also indicated a limited maternal transfer of $\mathrm{Hg}$ during pregnancy since levels in the tissues of foetuses were below 1 $\mu \mathrm{g}$ g- 1 w.wt. However, hepatic $\mathrm{Hg}$ levels in foetuses increased with body length, and were also proportionate to maternal hepatic, renal and muscular $\mathrm{Hg}$ levels. Lastly, affinities between $\mathrm{Hg}$ and $\mathrm{Se}$ in tissues would participate in $\mathrm{Hg}$ neutralisation in both mothers - through tiemannite granules - and fetuses - through reduced glutathione - counteracting the toxic effects linked to the particularly high quantities of methyl-Hg to which marine mammals are naturally exposed.
\end{abstract}

Keywords: Marine mammals; Mercury; Selenium; Pregnancy; North-Eastern Atlantic 


\section{Introduction}

During the last thirty years, a considerable body of data has been built up on pollutants levels in marine mammals (e.g. Wagemann and Muir, 1984; Law, 1996; Borrell and Reijnders, 1999). Indeed, due to their longevity and their elevated position in marine food webs, these organisms are generally considered as the integrators of the contamination of the environment (Reijnders, 1988). Some concerns have already been raised regarding adverse effects of pollutants, which include reproductive failures (e.g. Reijnders, 1980, 1986). Among generally focused contaminants, non essential heavy metals like cadmium $(\mathrm{Cd})$ and mercury $(\mathrm{Hg})$ are widely dispersed in the environment, since they are released from both natural and anthropogenic sources (Nriagu, 1996). Food is the major route of uptake of these elements for marine mammals, and consequently adult dolphins often display high metal levels in their tissues (Aguilar et al., 1999). Hence, the question of the importance of toxic metal transfer from mother to offspring is raised. Indeed, metals could be transferred from mothers to foetuses - via the placenta - and to suckling calves - via the milk - affecting them during their most sensitive periods of development. Generally, important metal exposure of human offspring to methyl-Hg can affect their normal neuronal development (WHO, 1990) whereas high dose of $\mathrm{Cd}$ during the gestational period can produce growth retardation in rat calves (Rohrer et al., 1979; Barantski et al., 1982). Such an altered growth is known to be induced by zinc (Zn) deficiency in foetuses, which may be caused by elevated maternal Cd impregnation (Brzoska and Moniusko-Jakoniuk, 2001).

Numerous laboratory experiments and epidemiological studies have enabled to better understand the modalities of transfer of trace elements to offspring and their associated toxic effects in rodents and humans (see the reviews of Bell, 1984 and of Chang, 1984). However, determining the impact of toxic contaminants in wildlife marine mammal populations is more 
difficult, because 1) causality relationships between contaminant levels and potential toxic effects are not evident to show in situ, and 2) sampling is opportunistic. Sample accessibility easily explains why little data is available on trace element bioaccumulation in foetuses of cetaceans and is generally limited to few individuals (Itano and Kawai, 1981; Honda and Tatsukawa, 1983; Fujise et al., 1998; Law et al., 1992; Caurant et al., 1993; Yang et al., 2004).

Samples for trace element measurements in cetaceans generally originate from two basic sources, i.e. strandings and direct or incidental catches. Strandings may be divided into single and mass events. In the first case, the chemical levels may not reflect sometimes those of healthy populations since stranded individuals could suffer from diseases or parasitisms and additionally exhibit a poor nutritional status (e.g. Frank et al., 1992; Olsson et al., 1994; Bennet et al., 2001; Das et al., 2004; Dehn et al., 2005). Such biases are likely to be excluded when using animals from mass living stranding events or accidental by-catchs.

This study focussed at mother-foetus pairs of short-beaked common dolphins (Delphinus delphis) from the North-Eastern Atlantic. We used two sources of samples, for which metal levels are likely to correctly reflect those of the healthy population, i.e. 1) a mass living stranding event composed of females and their calves, which got accidentally trapped during the ebb tide in a shallow bay of the English Channel (Pleubian, North coast of Brittany, February 2002) and 2) single stranding events of accidentally by-caught dolphins along the Atlantic French coastline (2002-2003). In these waters, common dolphins typically feed on fish and cephalopods (Pierce et al., 2004), which may expose them to a contamination risk by Hg (Bloom, 1992; Bustamante et al., 2006) and Cd (Bustamante et al., 1998; 2002). This cetacean species reach 20-30 years old, and its gestation period is about 11 months (Collet, 1981; Murphy, 2004). Such characteristics make the common dolphin a suitable species to 
clarify the importance of trace element gestational transfer in marine mammals. The investigated non essential elements were $\mathrm{Cd}$ and $\mathrm{Hg}$, plus essential elements interacting in their detoxification processes. Firstly, we focussed on copper $(\mathrm{Cu})$ and zinc $(\mathrm{Zn})$ measurements because they are contained in metallothioneins (MTs), which play a key role in Cd detoxification (see the review of Das et al., 2000a). Secondly, selenium (Se) levels were examined because of its well-known co-precipitation with $\mathrm{Hg}$, which lead to accumulation of non toxic granules of tiemannite (HgSe) in the liver (e.g. synthesis of Law, 1996). The present objectives were 1) to provide trace element levels in foetus-mother pairs of common dolphins, and 2) to determine which factors are likely to influence metal accumulation in foetuses.

\section{Material and methods}

This study is based on 17 foetus-mother pairs of common dolphins stranded along the French coasts. Most of the specimens (i.e. 10 pairs) originated from the mass living stranding event composed of 47 females and their calves (Pleubian, February 2002). The 7 other pairs were collected following single stranding events along the Atlantic French coastline during January months of 2002 and 2003. Post-mortems were carried out by veterinarians or by trained biologists of the Centre de Recherche sur les Mammifères Marins (CRMM) from the University of La Rochelle, and results were included in the European program BIOCET reports (Pierce et al., 2004). The nutritional condition of these animals, established from visual assessment of dorsal muscles and blubber thickness, was good in most cases $(\mathrm{n}=11)$ and medium in the other cases $(n=6)$. No individuals could be classified as showing a poor nutritional condition. Concerning single stranding events, carcasses were fresh (intact pigmentation, cloudy eyes, tern coloration of organs during dissection), except in the case of one individual, which was slightly decomposed (skin peeling, moderate smell of 
decomposition). Moreover, some external observations (broken rostrum, amputated flukes) have permitted to classify all these individuals as accidentally by-caught.

Note that before necropsy, total body length was measured (rostrum to fluke notch) and values for foetuses ranged from 32 to $60 \mathrm{~cm}$. In the North-Eastern Atlantic, common dolphins have a length of 90-100 cm at birth (Collet, 1981; Murphy, 2004). Thus, foetuses from this study would have been collected at early to mid-pregnancy periods.

Various tissues and organs were sampled during necropsies. Teeth of mothers were collected in order to determine age, following the recommendations of Perrin and Myrick (1980). One GLG (Growth Layer Group) is considered to represent one year in common dolphins (Gurevich et al., 1980) and ages were recorded to the nearest 0.5 GLG. In addition, the kidneys and the liver of foetuses and mothers were systematically sampled and stored in plastic bags at $-20^{\circ} \mathrm{C}$ for trace element analyses. Muscle and blood samples were collected from a subset of mothers and added to the sampling in order to investigate modalities of $\mathrm{Hg}$ transfer to foetuses. Blood was directly collected from pregnant females $(n=9)$ that died following the mass living stranding event and samples were stored into sterile polypropylene tubes.

With the exception of blood, all fresh samples were freeze-dried and ground to powder. The mean ratios between dry weight (d.wt.) and wet weight (w.wt.) were 0.30 for the muscle of mothers, and 0.22 and 0.28 for the liver, and 0.18 and 0.23 for the kidneys in foetuses and mothers, respectively. Each sample was then treated in duplicate. For total $\mathrm{Hg}$ measurements, aliquots ranging from 0.5 to $3 \mathrm{mg}$ of dried-material, as well as thawed whole-blood from mothers, were analysed directly in an Advanced Mercury Analyser spectrophotometer (Altec AMA 254). For the other trace element analyses, 2 aliquots of approximately $200 \mathrm{mg}$ of each 
homogenised dry sample were digested with $3.5 \mathrm{~mL}$ of $65 \% \mathrm{HNO}_{3}$ at $60^{\circ} \mathrm{C}$ for 3 days. The digested contents were then diluted to $10 \mathrm{~mL}$ in milli-Q quality water. Then $\mathrm{Cd}, \mathrm{Cu}$ and $\mathrm{Zn}$ contents were assayed using a flame (Varian 250 Plus) Atomic Absorption Spectrometer (AAS) with deuterium background correction whereas Se and some low $\mathrm{Cd}$ contents were analysed with graphite furnace AAS (Hitachi Z-5000) with Zeeman background correction. Quality controls were made using standard reference materials from National Research Council of Canada (NRCC), i.e. dogfish liver (DOLT-2 and DOLT-3), dogfish muscle (DORM-2), and lobster hepatopancreas (TORT-2). These reference materials were treated and analysed under the same conditions as the samples. Results were in good agreement with the certified values (Table 1). In addition, the laboratory participates in intercalibration exercises organised by the International Atomic Energy Agency (cf. Coquery et al., 1999). During the last exercise, our laboratory was classified in group 1, indicating the good quality of results for all analysed elements (Azemard et al., 2006). Detection limits ( $\mu \mathrm{g} . \mathrm{g}^{-1}$ d.wt.) were 0.004 for $\mathrm{Cd}, 0.5$ for $\mathrm{Cu}, 3$ for $\mathrm{Zn}, 0.8$ for $\mathrm{Se}$, and 0.005 for $\mathrm{Hg}$. All concentrations below the detection limit were replaced with "dummy values" that were half of the detection limit in order to allow further statistical comparisons (Gibbons and Coleman, 2001). Metal levels in dolphin tissues were expressed as $\mu \mathrm{g} \cdot \mathrm{g}^{-1}$ w.wt.

Spearman rank correlation coefficients were used 1) to determine intermetallic relationships in the kidneys and the liver of foetuses, mothers, and between the mother-foetus pairs, and 2) to establish correlations between trace elements and length of foetuses or age of mothers. Particular attention was paid to $\mathrm{Hg}$, for which foetus-mother relationships were investigated using maternal concentrations in blood, muscle, kidneys, and liver. 


\section{Results and discussion}

Table 2 gathers mean trace element levels in the tissues and blood of foetus and mother common dolphins stranded along the French coasts. With the exception of $\mathrm{Cd}$, all trace elements were present at higher concentrations in the liver of both foetuses and mothers. Note that foetuses from single stranding events were smaller than ones from the mass living stranding event. In addition, trace element levels in the liver and the kidneys of mothers were in the same range than those previously obtained for this species in European waters (Law et al., 1992; Holsbeek et al., 1998; Zhou et al., 2001; Carvalho et al., 2002; Das et al., 2000b; 2003; Lahaye et al., 2005; Lahaye, 2006) and no significant differences of non essential element levels were detected in females of various reproductive status (Lahaye, 2006).

\section{Cadmium, copper and zinc}

All foetuses of common dolphins displayed renal and hepatic $\mathrm{Cd}$ concentrations that were below the detection limit of AAS, as opposed to the relatively high Cd concentrations found in the tissues of some mothers (Table 2). Such low foetal Cd levels were previously reported in other cetacean species from various areas (Table 3).

According to Webb (1979), metallothioneins (MTs) may act as detoxifiers of Cd in animals which are able to accumulate this metal in their tissues as common dolphin mothers do. Furthermore, pregnant and lactating females have generally an increased induction of MTs to accommodate increasing demand and storage of essential elements (Solaiman et al., 2001). In pregnant females, Cd binding to MTs may also prevent the transfer of $\mathrm{Cd}$ across the placenta (Hanlon et al., 1982). From both human epidemiological studies and laboratory experiments on animals, it effectively appears that the placenta may provide to the foetus a certain degree 
of protection against Cd entrance (Bell, 1984). In fact, placenta itself contains MTs and it may serve as a filter for Cd by storing it (Itoh et al., 1996; Kuriwaki et al., 2005).

In adult marine mammals, $\mathrm{Cd}, \mathrm{Cu}$, and $\mathrm{Zn}$ are all contained in MTs (see the review of Das et al., 2000a). Both $\mathrm{Cu}$ and $\mathrm{Zn}$ have the ability to induce the biosynthesis of this protein (Kägi and Nordberg, 1979). The chemical similarity between Cd and Zn (Tsalev and Zaprianov, 1983) make Cd able to displace Zn ions from MTs (Mochizuki et al., 1985), which may result in a further synthesis of these proteins (Simkiss et al., 1982). The competition between Cd and $\mathrm{Zn}$ for the binding sites of MTs might involve a co-accumulation of $\mathrm{Cd}$ and $\mathrm{Zn}$ in tissues (Toyama et al., 1986; Wagemann et al., 1988), and especially in the kidneys where Cd levels are the highest. Only a fraction of the total $\mathrm{Cu}$ and $\mathrm{Zn}$ in tissues may also be bound to MTs, while practically all of the Cd in chronically exposed animals may occur as MTs or MT-like proteins (Wagemann and Hobden, 1986). Here, Cd and $\mathrm{Zn}$ were strongly and positively correlated in the kidneys of mothers $\left(\mathrm{R}_{\text {Spearman }}=0.932, \mathrm{P}<0.001\right.$, Table 4). Hence, owing to the expected binding of Cd to MTs in the kidneys of mothers, the transfer to offspring through the placenta might be prevented.

In the liver, $\mathrm{Cu}$ levels varied greatly between foetuses and mothers. The particular high $\mathrm{Cu}$ levels encountered in the liver of foetuses points out an important transplacental transfer of this metal (e.g. Underwood, 1977; Law, 1996; Wagemann et al., 1988; Yang et al., 2004). Elevated $\mathrm{Cu}$ levels in offspring could be due to either bioaccumulation of $\mathrm{Cu}$ during pregnancy with low excretion rates in foetus or a specific biochemical requirement for development (Wagemann et al., 1988). In other words, foetuses could have only limited $\mathrm{Cu}$ excretion via bile or elevated MTs in the liver to store essential elements for growth. Here, hepatic $\mathrm{Cu}$ concentrations were significantly and positively correlated to foetus length $\left(\mathrm{R}_{\text {Spearman }}=0.655, \mathrm{P}<0.001\right.$, Table 4$)$, which indicates an effective bioaccumulation of $\mathrm{Cu}$ 
during pregnancy. Moreover, the strong relationship between $\mathrm{Cu}$ and $\mathrm{Zn}$ in the kidneys of foetuses $\left(\mathrm{R}_{\text {Spearman }}=0.740, \mathrm{P}<0.001\right.$, Table 4) may reflect an involvement of MTs in the sequestration of those essential elements during pregnancy, as previously been reported in rats (Klaassen and Liu, 1997).

\section{Mercury and selenium}

Total Hg levels in foetuses were far lower than those of mothers (Table 2). In addition, $\mathrm{Hg}$ levels in common dolphin foetuses from the North Eastern Atlantic waters were comparable to those previously reported in foetuses of other cetacean species, but they were, to some extent, lower than those found in several species from the Pacific and the Faroe Islands (Table $3)$.

Both the increase of $\mathrm{Hg}$ levels with body length in the liver of foetuses $\left(\mathrm{R}_{\text {Spearman }}=0.821, \mathrm{P}<\right.$ 0.001, Table 4) and their positive correlations with hepatic, renal and muscular levels of mothers $\left(\mathrm{R}_{\text {Spearman }}>0.6, \mathrm{P}<0.001\right.$, Table 5) strongly suggest a maternal transfer of $\mathrm{Hg}$ during the prenatal life. However, this maternal $\mathrm{Hg}$ transfer would be rather limited since $\mathrm{Hg}$ levels in the tissues of foetuses were below $1 \mu \mathrm{g} \cdot \mathrm{g}^{-1}$ w.wt. (Table 2).

Only methyl-Hg may be able to go through the placenta (Chang, 1984; WHO, 1990). Previous works suggested that limited transplacental transfer of $\mathrm{Hg}$ in cetaceans is due to an efficient demethylation process in the liver of mothers, with the formation of tiemannite granules (HgSe), which in turn leads to low levels of methyl-Hg likely to be transferred to foetuses (e.g. Caurant et al., 1993; Law, 1996). The close relationship between $\mathrm{Hg}$ and $\mathrm{Se}$ in the liver of mothers $\left(\mathrm{R}_{\text {Spearman }}=0.961, \mathrm{P}<0.001\right.$, Table 4$)$ strongly comforts this hypothesis whereas the absence of such strong correlation in the liver of foetuses $\left(\mathrm{R}_{\text {Spearman }}=0.525, \mathrm{P}<0.05\right.$, 
Table 4) may indicate that this process is not active at this life stage. This result, together with the far excess of Se compared to $\mathrm{Hg}$ amounts in foetus livers, also emphasizes the fact that a threshold level of $\mathrm{Hg}$ is necessary to induce the formation of tiemmanite (e.g. Palmisano et al. 1995).

The inability of foetuses to demethylate $\mathrm{Hg}$ could make them more sensitive to methyl- $\mathrm{Hg}$ during their prenatal life. Maternal transfer of methyl-Hg can be estimated through measurements of $\mathrm{Hg}$ in mother blood. Total $\mathrm{Hg}$ levels found in blood of common dolphin mothers from the mass living stranding event ranged from 0.201 to $0.611 \mu \mathrm{g} . \mathrm{g}^{-1}$ w.wt., i.e. a mean of $0.426 \pm 0.120 \mu \mathrm{g} \cdot \mathrm{g}^{-1}$ w.wt. $(\mathrm{n}=9$; Table 2$)$, corresponding to a Hg level of $452 \pm 127$ $\mu \mathrm{g} . \mathrm{l}^{-1}$ in common dolphin blood. Higher $\mathrm{Hg}$ concentrations were found in Pacific mature striped dolphins, with a mean total $\mathrm{Hg}$ level of $1.4 \pm 0.4 \mu \mathrm{g} \cdot \mathrm{g}^{-1}$ w.wt. $(\mathrm{n}=9)$, of which $70 \%$ was methylated, i.e. mean methyl-Hg level of $0.95 \pm 0.45 \mu \mathrm{g} \cdot \mathrm{g}^{-1}$ w.wt. (Itano and Kawai, 1981). Most of this metal in dolphin blood is thus under organic form, as well as for other cetacean species (Hyatt et al., 1999; Nielsen et al., 2000). According to the methyl-Hg proportion found in the blood of Pacific striped dolphins, blood methyl-Hg mean concentration of our studied pregnant common dolphins could be estimated around $300 \mu \mathrm{g} \cdot \mathrm{l}^{-1}$. However, such result remains a rough estimate of maternal transfer of methyl-Hg because of the important variability of $\mathrm{Hg}$ concentrations likely to be encountered in blood. Indeed, $\mathrm{Hg}$ concentrations in blood may reflect only recent exposure to this metal, which may vary according to feeding activity and/or age (Nielsen et al., 2000; Dehn et al., 2005). Thus, Hg is taken up by all tissues from the bloodstream, and the initial phase of tissue distribution takes about 1 to 2 days after a single dose (see review by Clarkson, 1997). Moreover, the half time in blood has been evaluated to 44 days by Smith et al. (1994) and at least somewhat less than in the whole body- that is less than 80 days (WHO, 2000). Further investigations on factors influencing Hg concentrations in blood should have to be carried out. 
In human adults, the signs or symptoms of methyl-Hg poisoning become detectable at concentrations of about $200 \mu \mathrm{g} . \mathrm{l}^{-1}$ in blood (Lauwerys, 1990). Although equivalent or even higher concentrations are found in adult cetacean blood, no poisoning symptoms of $\mathrm{Hg}$ have been observed to date (Itano and Kawai, 1981; Hyatt et al., 1999; Nielsen et al., 2000). This clearly indicates that the adaptative capacities of marine mammals to demethylate $\mathrm{Hg}$ in their liver might modify the kinetic of $\mathrm{Hg}$ poisoning commonly described in other organisms. In this study, $\mathrm{Hg}$ concentrations in blood seem to indicate elevated short-time exposure of dolphins to methyl-Hg, which would be readily neutralised in the liver of mothers.

Despite the high Hg levels measured in the blood of mature striped dolphins (see above), Itano and Kawai (1981) observed relatively low $\mathrm{Hg}$ concentrations in the blood of foetuses, i.e. $0.16 \pm 0.07 \mu \mathrm{g} . \mathrm{g}^{-1}$ w.wt $(\mathrm{n}=4)$, but most of the metal was methyl-Hg $\left(0.15 \pm 0.06 \mu \mathrm{g} \cdot \mathrm{g}^{-1}\right.$ w.wt, i.e. $\left.16 \pm 6 \mu \mathrm{g} \cdot \mathrm{l}^{-1}\right)$. The authors suggested that, beside the already mentioned methylated form $(70 \%$ of total $\mathrm{Hg}), \mathrm{Hg}$ in the maternal blood may exist in a chemical form (i.e. combined with $\mathrm{Se}$ ) that would be not readily transferable across the placenta. Although such levels are likely to vary according to mother's diet, $\mathrm{Hg}$ concentrations in the blood of dolphin foetuses are higher than those expected to produce toxic effects in human offspring under a chronic exposure to methyl-Hg during pregnancy, i.e. $5.8 \mu \mathrm{g} . \mathrm{l}^{-1}$ methyl-Hg in cord blood (US NRC, 2000). However, direct effects of such an elevated methyl-Hg exposure to wild common dolphins remain difficult to determine.

In addition, through their dietary consumption of seafood, marine mammals may also benefit from important intakes of Se that protect them against methyl-Hg. Experiments in rodents have shown that Se could protect offspring against methyl-Hg toxic effects by preventing it to go through the foetal blood-brain barrier via a methyl-Hg trapping mechanism by glutathione (Fredriksson et al., 1993). In fact, dietary supplementation of Se may increase activities of 
certain enzymes like glutathione peroxydase and/or glutathione transferase, leading to an increase of reduced glutathione in tissues and blood (Schnell et al., 1988; Hassan et al., 1985), for which methyl-Hg has a great affinity (Thomas and Smith, 1979; Naganuma and Imura, 1979). Hence, total $\mathrm{Hg}$ concentrations in the blood of rodents fed with Se-enriched diet were higher than those fed on standard diet, as a result of the methyl-Hg trapping mechanism by glutathione (Fredriksson et al., 1993). Such processes might also occur in other mammals, like dolphins.

In common dolphins, hepatic $\mathrm{Hg}$ and Se accumulate with length in foetuses during gestation $\left(\mathrm{R}_{\text {Spearman, Hg }}=0.821, \mathrm{P}<0.01 ; \mathrm{R}_{\text {Spearman Se }}=0.552, \mathrm{P}<0.05\right)$ as well as with maternal hepatic $\mathrm{Hg}$ and Se levels (Table 4). Thus, molar concentrations of Se increase with $\mathrm{Hg}$ in foetus liver (Figure 1). However, $\mathrm{Hg}$ :Se molar ratio is not correlated with foetus body length since $\mathrm{Se}$ is far in excess compared to Hg (Figure 2). This excess may prevent the neurotoxic effects of methyl-Hg present in large proportion in their blood. Regarding the relatively low Hg levels encountered in the tissues of mother common dolphins (Table 2), maternal transfer of $\mathrm{Hg}$ through the placenta is also unlikely to cause severe effects to dolphin foetuses in European waters.

\section{Conclusions}

Trace element levels in common dolphin foetuses from the North Eastern Atlantic waters were relatively low compared to those encountered in several species from the Pacific and the Faroe Islands (Table 3). Furthermore, although $\mathrm{Hg}$ was shown to cross the placenta, the amounts that actually accumulated in the tissues of the foetuses were relatively low $\left(<1 \mu \mathrm{g} \cdot \mathrm{g}^{-}\right.$

${ }^{1}$ w.wt.), regarding the levels of methyl-Hg to which they may continuously be in contact with (around $300 \mu \mathrm{g} . \mathrm{l}^{-1}$ in maternal blood). Comparisons with epidemiological studies on humans 
and laboratory experiments on rodents highlighted that marine mammals may have developed efficient mechanisms to counteract the very high levels of methyl-Hg to which they are naturally exposed. Hence, affinities between $\mathrm{Hg}$ and $\mathrm{Se}$ may participate in detoxification mechanisms in both mothers through the formation of tiemannite granules, and foetuses through the binding to reduced glutathione.

\section{Acknowledgements}

Sampling was carried out by the Réseau National Echouages, co-ordinated by the Centre de Recherches sur les Mammifères Marins (CRMM) of La Rochelle. This work was funded by the European program BIOCET (EC: EVK3-CT-2000-00027) and through a research grant from the Conseil Régional de Poitou-Charentes of V.L.

\section{References}

Aguilar, A.; Borrel, A.; Pastor, T. Biological factors affecting variability of persistent pollutant levels in cetaceans. In: Reijnders, P.; Aguilar, A.; Donovan, G., eds. Chemical pollutants and cetaceans, vol. special issue 1, Journal of Cetacean Research and Management, UK, pp. 83-116; 1999.

Azemard, S.; de Mora, S.J.; Guitart, C.; Wyse, E. World-wide intercomparison exercise for the determination of trace elements and methylmercury in tunafish flesh homogenate IAEA436. Report $\mathrm{n}^{\circ}$ IAEA/AL/157 IAEA/MEL/77, 98p; 2006. 
Baranski, B.; Stetkiewicz, I.; Trzcinka-Ochocka, M.; Sitarek, K.; Szymczak, W. Teratogenicity, fetal toxicity and tissue concentration of cadmium administered to female rats during organogenesis. J. Appl. Toxicol. 2:255-259; 1982.

Bell, J. The toxicity of cadmium in the newborn. In: Kacew, S.; Reasor, M.J., eds. Toxicology and the newborn, Elsevier Science Publisher B.V., pp. 201-215; 1984.

Bennett, P.M.; Jepson, P.D.; Law, R.J.; Jones, B.R.; Kuiken, T.; Baker, J.R.; Rogan, E.; Kirkwood, J.K. Exposure to heavy metals and infectious disease mortality in harbour porpoises from England and Wales. Environ. Pollut. 112:33-40; 2001.

Bloom, N.S. On the chemical form of mercury in edible fish and marine invertebrate tissue. Can. J. Fish. Aquat. Sci. 49:1010-1016; 1992.

Borrell, A.; Reijnders, P.J.H. Summary of temporal trends in pollutant levels observed in marine mammals. In: Reijnders, P.; Aguilar, A.; Donovan, G.P., eds. Chemical pollutants and cetaceans, Special Issue 1. Journal of Cetacean Research and Management, UK, pp. 149-155; 1999.

Bustamante, P.; Caurant, F.; Fowler, S.W.; Miramand, P. Cephalopods as a vector for the transfer of cadmium to top marine predators in the north-east Atlantic Ocean. Sci. Total Environ. 220:71-80; 1998. 
Bustamante, P.; Cosson, R.P.; Gallien, I.; Caurant, F.; Miramand, P. Cadmium detoxification processes in the digestive gland of cephalopods in relation to accumulated cadmium concentrations. Mar. Environ. Res. 53:227-241; 2002.

Bustamante, P.; Lahaye, V.; Durnez, C.; Churlaud, C., Caurant, F. Total and organic Hg concentrations in cephalopods from the North East Atlantic waters: influence of geographical origin and feeding ecology. Sci. Total Environ. 368:585-596; 2006.

Brzoska, M. M.; Moniuszko-Jakoniuk, J. Interactions between cadmium and zinc in the organism. Food Chem. Toxicol. 39:967-980; 2001.

Carvalho M.L.; Pereira R.A.; Brito J. Heavy metals in soft tissues of Tursiops truncatus and Delphinus delphis from west Atlantic Ocean by X-ray spectrometry. Sci. Total Environ. 292: 247-254; 2002.

Caurant, F.; Amiard-Triquet, C.; Amiard, J.C. Factors influencing the accumulation of metals in pilot whales (Globicephala melas) off the Faroe Islands. In: Donovan, G.P.; Lockyer, C.; Martin, A.R., eds. Biology of northern hemisphere pilot whales, Report of the International Whaling Commission, Special Issue 14, pp. 369-390; 1993.

Chang, L.W. Developmental toxicology of methylmercury. In: Kacew, S.; Reasor, M.J., eds. Toxicology and the newborn, Elsevier Science Publisher B.V., pp. 175-200; 1984.

Clarkson, T.W. The toxicology of mercury. Crit. Rev. Clin. Lab. Sci. 34: 369-403; 1997. 
Collet A. Biologie du dauphin commun, Delphinus delphis L., en Atlantique nord-est. Thèse d’Université, Université de Poitiers, France, 156p ; 1981.

Coquery, M.; Carvalho, F.P.; Azemard, S.; Horvat, M. The IAEA worldwide intercomparison exercises (1990-1997): determination of trace elements in marine sediments and biological samples. Sci. Total Environ. 237-238:501-508; 1999.

Das, K.; Debacker, V.; Bouquegneau, J.M. Metallothioneins in marine mammals. Cell. Mol. Biol. 46:283-294; 2000a.

Das, K.; LePoint, G.; Loizeau, V.; Debacker, V.; Dauby, P.; Bouquegneau, J.M. Tuna and dolphin association in the north-east Atlantic: evidence of different ecological niches from stable isotope and heavy metal measurements. Mar. Pollut. Bull. 40:102-109; 2000b.

Das, K.; Beans, C.; Holsbeek, L.; Mauger, G.; Berrow, S.D.; Rogan, E.; Bouquegneau, J.M. Marine mammals from northeast Atlantic: relationship between their trophic status as determined by $\delta^{13} \mathrm{C}$ and $\delta^{15} \mathrm{~N}$ measurements and their trace metal concentrations. Mar. Environ. Res. 56:349-365; 2003.

Das, K.; Siebert, U.; Fontaine, M.; Jauniaux, T.; Holsbeek, L.; Bouquegneau, J.M. Ecological and pathological factors related to trace metal concentrations in harbour porpoises Phocoena phocoena from the North Sea and adjacent areas. Mar. Ecol. Progr. Ser. 281:283-295; 2004. 
Dehn, L.A.; Sheffield, G.G.; Follmann, E.H.; Duffy, L.K.; Thomas, D.L.; Bratton, G.R.; Taylor, R.J.; O’Hara, T.M. Trace elements in tissues of phocids seals harvested in the Alaska and Canadian Arctic: influence of age and feeding ecology. Can. J. Zool. 83:726-746; 2005.

Frank, A.; Galgan, V.; Roos, A.; Olsson, M.; Petersson, L.R.; Bignert, A. Metal concentrations in seals from Swedish waters. Ambio 21:529-538; 1992.

Fredriksson, A.; Gårdlund, A.T.; Bergman, K.; Oskarsson, A.; Ohlin, B.; Danielsson, B.; Archer, T. Effects of maternal dietary supplementation with selenite on the postnatal development of rat offspring exposed to methyl mercury in utero. Pharmacol. Toxicol. 72:377-382; 1993.

Fujise, Y.; Honda, K.; Tatsukawa, R.; Mishima, S. Tissue distribution of heavy metals in Dall's porpoises in the Northwestern Pacific. Mar. Pollut. Bull. 19:226-230; 1988.

Gibbons, R.D.; Coleman, D.E. Statistical methods for detection and quantification of environmental contamination. John Wiley \& Sons, New York, 384pp; 2001.

Gurevich, V.S.; Stewart, L.H.; Cornell, L.H. The use of tetracycline in age determination of common dolphins, Delphinus delphis. In: Perrin, W.F.; Myrick, A.C., eds. Age determination of toothed whales and sirenians. Report of the International Whaling Commission, Special Issue 3, Cambridge, UK, pp. 165-169; 1980.

Hanlon, D.P.; Specht, C.; Ferm, V.H. The chemical status of cadmium ion in the placenta. Environ. Res. 27:89-94; 1982. 
Hassan, M.O.; Stohs, S.J.; Murray, W.J.; Birt, D.F. Dietary selenium, glutathione peroxidase activity, and toxicity of 2,3,7,8-tetrachloro-dibenzo-p-dioxin. J. Toxicol. Environ. Health $15: 405-415 ; 1985$.

Holsbeek, L.; Siebert, U.; Joiris, C.R. Heavy metals in dolphins stranded on the French Atlantic coast. Sci. Total Environ. 217:241-249; 1998.

Honda, K.; Tatsukawa, R. Ecology and bioaccumulation of Stenella coeruleoalba - heavy metal concentration in the muscle and liver tissue of Stenella coeruleoalba. In: Fujiyama, T., ed. Studies on the levels of organochlorine compounds and heavy metals in the marine organism, University of the Ryukyus, pp. 25-47; 1981.

Honda, K.; Tatsukawa, R. Distribution of cadmium and zinc in tissues and organs, and their age-related changes in striped dolphins, Stenella coeruleoalba. Arch. Environ. Contam. Toxicol. 12:543-550; 1983.

Hyatt, C.K.; Trebacz, E.; Metner, D.A.; Wagemann, R.; Lockhart, W.L. Mercury and selenium in the blood and tissues of Beluga whales from the western Canadian arctic. In: Mercury as a global pollutant $-5^{\text {th }}$ international conference, May 1999, Rio de Janeiro, Brasil, pp. $278 ; 1999$.

Itano, K.; Kawai, S. Mercury and selenium levels in the striped dolphins in the Pacific coast of Japan. In: Fujiyama, T., ed. Studies on the levels of organochlorine compounds and heavy metals in the marine organism, University of the Ryukyus, pp.73-84; 1981. 
Itoh, N.; Fujita, Y.; Nakanishi, H.; Kawai, Y.; Mayumi, T.; Hawang, G.S. et al. Binding of Cd to metallothionein in the placenta of Cd-treated mouse. J. Toxicol. Sci. 21:19-27; 1996.

Kägi, J.H.R.; Nordberg, M. Metallothionein. In: Kägi, J.H.R.; Nordberg, M., eds. Proceedings of the 1st international meeting on metallothionein and other low molecular weight metalbinding proteins. Zurich July 17-22 1978. Boston: Birkhauser Verlag, Experientia Supplement 34; 1979.

Klaassen, C.D.; Liu, J. Role of metallothioneins in cadmium-induced hepatoxicity and nephrotoxicity. Drug Metabolism Rev. 29:79-102; 1997.

Kuriwaki, J.; Nishijo, M.; Honda, R.; Tawara, K.; Nakagawa, H.; Hori, E.; Nishijo, H. Effects of cadmium exposure during pregnancy on trace elements in fetal rat liver and kidney. Toxicol. Letters 156:369-376; 2005.

Lahaye, V.; Bustamante, P.; Spitz, J.; Dabin, W.; Das, K.; Pierce, G.J.; Caurant, F. Long-term dietary segregation of short-beaked common dolphins (Delphinus delphis) in the Bay of Biscay determined using cadmium as an ecological tracer. Mar. Ecol. Progr. Ser. 305:275$285 ; 2005$.

Lahaye, V. Les éléments traces chez les petits cétacés des eaux européennes : utilisation du cadmium $(\mathrm{Cd})$ et du mercure $(\mathrm{Hg})$ comme traceurs de populations. Thèse d'Université, Université de La Rochelle, France, 300p; 2006. 
Lahaye, V.; Bustamante, P.; Law, R.J.; Learmonth, J.A.; Santos M.P.; Boon, J.P.; Rogan, E.; Dabin, W.; Addink, M.J.; Lopez, A.; Zuur, A.F.; Pierce, G.J.; Caurant, F. Biological and ecological factors related to trace element levels in harbour porpoises (Phocoena phocoena) from European waters. Mar. Environ. Res; In press.

Lauwerys, R.R. Cadmium. In: Lauwerys, R.R., ed. Toxicologie industrielle et intoxication professionnelle, Masson, Paris, pp. 136-149; 1990.

Law, R.J.; Jones, B.R.; Baker, J.R.; Kennedy, S.; Milne, R.; Morris, R.J. Trace metals in the livers of marine mammals from the Welsh coast and the Irish Sea. Mar. Pollut. Bull. 24:296$304 ; 1992$.

Law, R.J. Metals in marine mammals. Environmental Contaminants in Wildlife: Interpreting Tissue Concentrations. In: Beyer, W.N.; Heinz; G.H.; Redmond-Norwood, A.W., eds. CRC Press, pp. 357-375; 1996.

Mochizuki, Y.; Suzuki, K.T.; Sunaga, H.; Kobayashi, T.; Doi, R. Separation and characterization of metallothionein in two species of seals by high performance liquid chromatography-atomic absorption spectrophotometry. Comp. Biochem. Phys. C 82: 249-254; 1985.

Murphy, S. The biology and ecology of the common dolphin Delphinus delphis in the Northeast Atlantic. PhD thesis, University College Cork, 283p; 2004. 
Naganuma, A.; Imura, N. Methylmercury binds to a low molecular weight substance in rabbit and human erythrocytes. Toxicol. Appl. Pharmacol. 47:613-616; 1979.

Nielsen, J.B.; Nielsen, F.; Jørgensen, P.J.; Grandjean, P. Toxic metals and selenium in blood from pilot whales (Globicephala melas) and sperm whales (Physeter catodon). Mar. Pollut. Bull. 40:348-351; 2000.

Nriagu, J.O. A history of global metal pollution. Science 272:223-224; 1996.

Olsson, M.; Karlsson, B.; Ahnland, E. Diseases and environmental contaminants in seals from the Baltic and Swedish west coast. Sci. Total Environ. 154:217-227; 1994.

Palmisano, F.; Cardellicchio, N.; Zambonin, P.G. Speciation of mercury in dolphin liver: a two-stage mechanism for the demethylation accumulation process and role of selenium. Mar. Environ. Res. 40:109-121; 1995.

Perrin, W.F.; Myrick, A.C. Age determination of toothed whales and sirenians. Report of the International Whaling Commission, Special Issue 3, Cambridge, UK, 229 pp; 1980.

Pierce, G.J.; Santos, M.B.; Learmonth, J.A.; Smeenk, C.; Addink, M.; García Hartmann, M.; Boon, J.P.; Zegers, B.; Mets, A.; Ridoux, V.; Caurant, F.; Bustamante, P.; Lahaye, V.; Guerra, A.; González, A.; López, A.; Alonso, J.M.; Rogan, E.; Murphy, S.; Van Canneyt, O.; Dabin, W.; Spitz, J.; Dorémus, G.; Meynier, L. Bioaccumulation of persistent organic pollutants in small cetaceans in European waters: transport pathways and impact on reproduction. Final 
Report to the European Commission's Directorate General for Research on Project EVK32000-00027; 2004.

Reijnders, P.J.H. Organochlorine and heavy metal residues in harbour seals from the Wadden sea and their possible effects on reproduction. Neth. J. Sea Res. 14:30-65; 1980.

Reijnders, P.J.H. Reproductive failure in common seals feeding on fish from polluted coastal waters. Nature 324, 456-457; 1986.

Reijnders, P.J.H. Ecotoxicological perspectives in marine mammalogy: research principles and goals for a conservation policy. Mar. Mamm. Sci. 4:91-102; 1988.

Rohrer, S.R.; Shaw, S.M.; Lamar, C.H. Cadmium fetoxicity in rats following prenatal exposure. Bull. Environ. Contam. Toxicol. 23:25-29; 1979.

Schnell, R.C.; Park, R.S.; Davies, M.H.; Merrick, B.A.; Weir, S.W. Protective effects of selenium on acetaminophen-induced hepatotoxicity in rats. Toxicol. Appl. Pharmacol. 95:1$11 ; 1988$.

Simkiss, K.; Taylor, M.; Mason, A.Z. Metal detoxification and bioaccumulation in molluscs. Mar. Biol. Letters 3, 187-201; 1982.

Smith, J.C.; Allen, P.; Turner, M.D.; Most, B.; Fisher, H.L.; Hall, L.L. The kinetics of intravenously administered methylmercury in man. Toxicol. Appl. Pharmacol. 128: 251-256; 1994. 
Solaiman, D.; Jonah, M.M.; Miyasaki, W.; Ho, G.; Bhattacharyya, M.H. Increased metallothionein in mouse liver, kidneys, and duodenum during lactation. Toxicol. Sci. 60:184-192; 2001.

Thomas, D.J.; Smith, J.C. Partial characterization of a low-molecular weight methylmercury complex in rat cerebrum. Toxicol. Appl. Pharmacol. 47:547-556; 1979.

Toyama, C.; Himeno, S.; Watanabe, C.; Suzuki, T.; Morita, M. The relationship of the increased level of metallothionein with heavy metal levels in the tissues of harbour seals (Phoca vitulina). Ecotoxicol. Environ. Saf. 12:85-94; 1986.

Tsalev, D.L.; Zaprianov, Z.K. Atomic absorption spectrometry in occupational and environmental health practice. Boca Raton: CRC Press, 252 pp; 1983.

Underwod E.J. Trace elements in human and animal nutrition (4th ed.) Academic Press, New York, 545 pp; 1977.

US NRC (United States National Research Council). Toxicological effects of methylmercury. National Academic Press, Washington, DC; 2000.

Wagemann, R.; Muir, D.C.G. Concentrations of heavy metals and organochlorines in marine mammals of northern waters: overview and evaluation. Canadian Technical Report of Fisheries and Aquatic Sciences 1279, 97 pp; 1984. 
Wagemann, R.; Hobden, B. Low-molecular weight metalloproteins in tissues of the narwhal (Monodon monoceros). Comp. Biochem. Physiol. 84C:325-344; 1986.

Wagemann, R.; Stewart, R.E.A.; Lockhart, W.L.; Stewart, B.E.; Povoledo, M. Trace metals and methyl mercury: associations and transfer in harp seal (Phoca groenlandica) mothers and their pups. Mar. Mamm. Sci. 4:339-355; 1988.

Webb, M. Interactions of cadmium with cellular components. In: Webb, M., ed. The chemistry, biochemistry and biology of cadmium, Elsevier/North Holland, Biomedical Press, New York, pp. 285-340; 1979.

WHO. Environmental Healthy Criteria 101: Methylmercury. World Health Organization, Geneva, Switzerland, 144 pp; 1990.

WHO. Air Quality Guidelines, Second Edition, Chapter 6.9 Mercury. World Health Organization Regional Office for Europe, Copenhagen, Denmark, 15 pp; 2000.

Yang, J.; Kunito, T.; Anan, Y.; Tanabe, S.; Miyasaki, N. Total and subcellular distribution of trace elements in the liver of a mother-fetus of Dall's porpoises (Phocoenoides dalli). Mar. Pollut. Bull. 48:1122-1129; 2004.

Zhou, J.L.; Salvador, S.M.; Liu, Y.P.; Sequeira, M. Heavy metals in the tissues of common dolphins (Delphinus delphis) stranded on the Portuguese coast. Sci. Total Environ. 273:61-76; 2001. 
Table 1. Trace element levels (mean $\pm \mathrm{SD} ; \mu \mathrm{g} \cdot \mathrm{g}^{-1} \mathrm{~d} . \mathrm{wt}$.) in standard reference materials.

\begin{tabular}{|c|c|c|c|c|c|c|c|c|}
\hline \multirow{3}{*}{ Metals } & \multicolumn{8}{|c|}{ Standard reference materials (NRCC) } \\
\hline & \multicolumn{2}{|c|}{ TORT-2 } & \multicolumn{2}{|c|}{ DORM-2 } & \multicolumn{2}{|c|}{ DOLT-2 } & \multicolumn{2}{|c|}{ DOLT-3 } \\
\hline & $\begin{array}{c}\text { Certified } \\
\text { value }\end{array}$ & $\begin{array}{l}\text { Observed } \\
\text { value }\end{array}$ & $\begin{array}{l}\text { Certified } \\
\text { value }\end{array}$ & Observed value & $\begin{array}{c}\text { Certified } \\
\text { value }\end{array}$ & $\begin{array}{l}\text { Observed } \\
\text { value }\end{array}$ & $\begin{array}{l}\text { Certified } \\
\text { value }\end{array}$ & $\begin{array}{l}\text { Observed } \\
\text { value }\end{array}$ \\
\hline $\mathrm{Cd}$ & $26.7 \pm 0.6$ & $26.2 \pm 0.2$ & $0.046 \pm 0.008$ & $0.046 \pm 0.001$ & $20.8 \pm 0.5$ & $20.6 \pm 0.4$ & $19.4 \pm 0.6$ & $19.2 \pm 0.4$ \\
\hline $\mathrm{Cu}$ & - & - & - & - & $25.8 \pm 1.1$ & $26.2 \pm 1.0$ & $31.2 \pm 1.0$ & $30.1 \pm 0.8$ \\
\hline $\mathrm{Hg}$ & $0.27 \pm 0.06$ & $0.28 \pm 0.02$ & $4.64 \pm 0.26$ & $4.46 \pm 0.20$ & $2.14 \pm 0.28$ & $2.08 \pm 0.11$ & $3.37 \pm 0.14$ & $3.36 \pm 0.02$ \\
\hline $\mathrm{Se}$ & - & - & - & - & $6.06 \pm 0.49$ & $5.82 \pm 0.40$ & $7.06 \pm 0.48$ & $6.70 \pm 0.56$ \\
\hline $\mathrm{Zn}$ & - & - & - & - & $85.8 \pm 2.5$ & $86.5 \pm 2.3$ & $86.6 \pm 2.4$ & $85.1 \pm 4.3$ \\
\hline
\end{tabular}


Table 2. Trace element levels (Mean $\pm \mathrm{SD} ; \mu \mathrm{g} . \mathrm{g}^{-1}$ w.wt.) in the tissues and blood of foetus-mother pairs of common dolphins. NB: $*$ Length is used for foetuses whereas age stands for mothers; LD: limit of detection; nd: not determined.

\begin{tabular}{|c|c|c|c|c|c|c|c|c|}
\hline \multicolumn{3}{|c|}{ Sample characteristics } & \multicolumn{6}{|c|}{ Trace element levels ( $\mu \mathrm{g} \cdot \mathrm{g}^{-1}$ w.wt.) } \\
\hline Sampling area & ID & $\begin{array}{c}\text { Length }(\mathrm{cm}) \\
\text { or age * }\end{array}$ & Tissue & $\mathrm{Cd}$ & $\mathrm{Cu}$ & $\mathrm{Hg}$ & $\mathrm{Se}$ & $\mathrm{Zn}$ \\
\hline \multirow{2}{*}{$\begin{array}{l}\text { Bay of Biscay } \\
\text { (single stranding } \\
\text { events; } n=7 \text { ) }\end{array}$} & foetus & $\begin{array}{l}39.3 \pm 3.9 \\
(32-45)\end{array}$ & $\begin{array}{l}\text { liver } \\
\text { kidney }\end{array}$ & $\begin{array}{l}<\mathrm{LD} \\
<\mathrm{LD}\end{array}$ & $\begin{array}{c}26.6 \pm 5.6 \\
(17.1-32.4) \\
2.1 \pm 0.2 \\
(1.7-2.3)\end{array}$ & $\begin{array}{c}0.30 \pm 0.09 \\
(0.18-0.42) \\
0.16 \pm 0.04 \\
(0.07-0.20)\end{array}$ & $\begin{array}{c}1.12 \pm 0.31 \\
(0.51-1.43) \\
0.33 \pm 0.11 \\
(0.20-0.53)\end{array}$ & $\begin{array}{c}34.2 \pm 11.6 \\
(21.7-47.5) \\
14.5 \pm 2.2 \\
(9.9-16.1)\end{array}$ \\
\hline & mother & $\begin{array}{l}15.7 \pm 3.7 \\
(10-22)\end{array}$ & $\begin{array}{l}\text { liver } \\
\text { kidney } \\
\text { muscle } \\
(\mathrm{n}=6)\end{array}$ & $\begin{array}{c}0.64 \pm 0.25 \\
(0.41-1.16) \\
2.13 \pm 0.80 \\
(1.21-3.18) \\
\text { nd }\end{array}$ & $\begin{array}{c}6.6 \pm 0.6 \\
(5.5-7.3) \\
3.0 \pm 0.9 \\
(2.4-4.9) \\
\text { nd }\end{array}$ & $\begin{array}{c}21.8 \pm 9.4 \\
(11.7-38.9) \\
1.47 \pm 0.36 \\
(0.95-1.89) \\
0.67 \pm 0.17 \\
(0.37-0.88)\end{array}$ & $\begin{array}{c}10.9 \pm 3.9 \\
(6.1-18.3) \\
3.41 \pm 1.02 \\
(1.58-4.75) \\
\text { nd }\end{array}$ & $\begin{array}{c}35.2 \pm 4.7 \\
(28.9-41.8) \\
19.1 \pm 1.2 \\
(16.6-20.5) \\
\text { nd }\end{array}$ \\
\hline \multirow[b]{2}{*}{$\begin{array}{l}\text { English Channel } \\
\text { (mass living } \\
\text { stranding event; } \mathrm{n} \\
\quad=10 \text { ) }\end{array}$} & foetus & $\begin{array}{l}51.4 \pm 7.2 \\
(37-60)\end{array}$ & kidney & $\begin{array}{l}<\mathrm{LD} \\
<\mathrm{LD}\end{array}$ & $\begin{array}{c}50.4 \pm 12.7 \\
(31.6-74.8) \\
2.4 \pm 0.3 \\
(1.9-2.9)\end{array}$ & $\begin{array}{c}0.49 \pm 0.12 \\
(0.26-0.66) \\
0.19 \pm 0.04 \\
(0.14-0.25)\end{array}$ & $\begin{array}{c}1.89 \pm 0.46 \\
(1.15-2.50) \\
0.34 \pm 0.04 \\
(0.26-0.43)\end{array}$ & $\begin{array}{c}32.9 \pm 7.7 \\
(26.2-47.5) \\
17.1 \pm 1.1 \\
(15.0-18.5)\end{array}$ \\
\hline & mother & $12.6 \pm 1.4$ & $\begin{array}{l}\text { liver } \\
\text { kidney } \\
\text { muscle } \\
\text { blood } \\
(\mathrm{n}=9)\end{array}$ & $\begin{array}{c}3.2 \pm 4.1 \\
(0.43-12.1) \\
11.3 \pm 9.4 \\
(3.9-28.8) \\
\text { nd } \\
\text { nd }\end{array}$ & $\begin{array}{c}7.3 \pm 1.5 \\
(4.8-9.2) \\
2.8 \pm 0.4 \\
(2.4-3.8) \\
\text { nd } \\
\text { nd }\end{array}$ & $\begin{array}{c}50.3 \pm 29.6 \\
(25.5-116.5) \\
3.98 \pm 1.16 \\
(3.03-6.29) \\
1.27 \pm 0.30 \\
(0.84-1.89) \\
0.43 \pm 0.12 \\
(0.20-0.61)\end{array}$ & $\begin{array}{c}20.7 \pm 10.8 \\
(11.7-46.5) \\
5.56 \pm 0.67 \\
(4.26-6.56) \\
\text { nd } \\
\text { nd }\end{array}$ & $\begin{array}{c}41.2 \pm 5.1 \\
(30.5-45.9) \\
25.9 \pm 4.2 \\
(22.9-35.1) \\
\text { nd } \\
\text { nd }\end{array}$ \\
\hline
\end{tabular}


Table 3. Trace element levels (Mean $\pm \mathrm{SD} ; \mu \mathrm{g} \cdot \mathrm{g}^{-1}$ w.wt.) in the kidneys and the liver of cetacean foetuses (literature data). NB: na, not available.

\begin{tabular}{|c|c|c|c|c|c|c|c|c|c|c|}
\hline \multicolumn{3}{|c|}{ Sample characteristics } & \multicolumn{7}{|c|}{ Trace element levels ( $\mu$ g.g $\mathrm{g}^{-1}$ w.wt.) } & \multirow{2}{*}{ References } \\
\hline Species & Sampling area & Length $(\mathrm{cm})$ & Tissue & $\mathrm{N}$ & $\mathrm{Cd}$ & $\mathrm{Cu}$ & $\mathrm{Hg}$ & $\mathrm{Se}$ & $\mathrm{Zn}$ & \\
\hline Delphis delphis & Ireland & na & liver & 1 & $<\mathrm{LD}$ & 40 & 0.5 & na & 15 & Law et al., 1992 \\
\hline \multirow[t]{2}{*}{ Phocoena phocoena } & Ireland & 51.8 & liver & 2 & $<\mathrm{LD}$ & 73.1 & 0.59 & 0.76 & 36.3 & Lahaye et al., in press \\
\hline & & 63.5 & kidney & 1 & 0.05 & 1.79 & 0.17 & na & 24.7 & \\
\hline \multirow[t]{2}{*}{ Phocoenoides dalli } & Pacific Ocean & 96 & liver & 1 & 0.006 & 82.2 & na & na & 40.9 & \\
\hline & & 96 & kidney & 1 & 0.003 & 2.55 & na & na & 23.7 & Fujise et al., 1988 \\
\hline Phocoenoides dalli & Pacific Ocean & 55 & liver & 1 & 0.052 & 60.9 & 0.82 & 5.3 & 25 & Yang et al., 2004 \\
\hline \multirow[t]{2}{*}{ Stenella coeruleoalba } & Pacific Ocean & na & liver & 16 & na & na & $1.76 \pm 0.69$ & $2.03 \pm 1.03$ & na & Itano and Kawai, 1981 \\
\hline & & na & kidney & 15 & na & na & $0.60 \pm 0.16$ & $0.67 \pm 0.28$ & na & \\
\hline \multirow[t]{2}{*}{ Stenella coeruleoalba } & Pacific Ocean & na & liver & 11 & 0.003 & 50.9 & na & na & 37.7 & Honda and Tatsukawa, 1981 \\
\hline & & na & kidney & 14 & $<\mathrm{LD}$ & na & na & na & $17.4 \pm 3.6$ & Honda and Tatsukawa, 1983 \\
\hline \multirow{3}{*}{ Globicephala melas } & Faroe Islands & na & liver & 3 & $0.004 \pm 0.001$ & $39.1 \pm 5.3$ & $0.36 \pm 0.15$ & $0.90 \pm 0.56$ & $33.0 \pm 15.4$ & Caurant et al., 1993 \\
\hline & (different schools) & na & liver & 5 & $0.020 \pm 0.010$ & $41.9 \pm 10.0$ & $1.07 \pm 0.53$ & $1.22 \pm 0.48$ & $47.5 \pm 24.6$ & \\
\hline & & na & liver & 5 & $0.037 \pm 0.015$ & $57.3 \pm 14.8$ & $0.83 \pm 0.40$ & $2.43 \pm 1.43$ & $54.7 \pm 36.0$ & \\
\hline
\end{tabular}


Table 4. Associations between trace elements, length of foetuses, age of mothers (independent variables) and dependent variables at $0.90<\mathrm{P} \leq 0.95$ (not underlined), $0.95<\mathrm{P} \leq 0.99$ (underlined) and $\mathrm{P}<0.99$ (double underlined). The direction of the correlation coefficient of Spearman is indicated by algebraic sign in front of the independent variable. NB: * Independent variables refer to mother data.

\begin{tabular}{|c|c|c|}
\hline \multirow{2}{*}{$\begin{array}{c}\text { Dependent } \\
\text { variable }\end{array}$} & \multicolumn{2}{|c|}{ Independent variable } \\
\hline & Liver & Kidney \\
\hline & \multicolumn{2}{|c|}{ Fœtus-mother pair interactions* } \\
\hline $\mathrm{Hg}$ & $+\mathrm{Hg},+\mathrm{Se}$ & \\
\hline $\mathrm{Se}$ & $\overline{+\mathrm{Cu}}$ & \\
\hline $\mathrm{Cd}$ & & $\underline{-\mathrm{Hg}}, \underline{-\mathrm{Cd}},-\mathrm{Zn}$ \\
\hline $\mathrm{Cu}$ & $+\mathrm{Hg},+\mathrm{Se}$ & $+\mathrm{Se}$ \\
\hline \multirow[t]{2}{*}{$\mathrm{Zn}$} & & $\underline{\underline{\underline{\mathrm{Se}}}}, \underline{\underline{+\mathrm{Cd}}}, \underline{\underline{+\mathrm{Zn}}},++\mathrm{Hg}$ \\
\hline & \multicolumn{2}{|c|}{ Whithin fœtuses only } \\
\hline $\mathrm{Hg}$ & $\underline{\underline{+ \text { Length }}}, \underline{\underline{+\mathrm{Cu}}}, \underline{+\mathrm{Se}}$ & \\
\hline $\mathrm{Se}$ & $\overline{+\mathrm{Cu}},+\mathrm{Hg},+$ Length & \\
\hline $\mathrm{Cd}$ & & -Length \\
\hline $\mathrm{Cu}$ & $+\mathrm{+Hg}, \underline{\underline{+\mathrm{Se}}}, \underline{\underline{+ \text { Length }}}$ & $\underline{\underline{+\mathrm{Zn}}}$ \\
\hline \multirow[t]{2}{*}{$\mathrm{Zn}$} & & $\underline{\underline{+\mathrm{Cu}}}, \underline{+ \text { Length }}$ \\
\hline & \multicolumn{2}{|c|}{ Whithin mothers only } \\
\hline $\mathrm{Hg}$ & + Se, + Age & + Age, + +Se, $++\mathrm{Cd},+\mathrm{Zn}$ \\
\hline $\mathrm{Se}$ & $\overline{+\mathrm{Hg}}$ & $+\overline{+\mathrm{Hg}},+\overline{\underline{\mathrm{Cd}}},+\overline{\underline{\mathrm{Zn}}}$ \\
\hline $\mathrm{Cd}$ & & $\overline{\underline{+\mathrm{Zn}}}, \overline{+\mathrm{Hg}}, \overline{\underline{+\mathrm{Se}}}$ \\
\hline $\mathrm{Cu}$ & & \\
\hline $\mathrm{Zn}$ & & $++\mathrm{Cd},+\mathrm{Hg},+\underline{\underline{\mathrm{Se}}}$ \\
\hline
\end{tabular}


Table 5. Spearman rank correlation coefficients between $\mathrm{Hg}$ levels in foetuses (liver, kidney) and mothers (liver, kidney, muscle, blood) at $0.90<\mathrm{P} \leq 0.95$ (not underlined), $0.95<\mathrm{P} \leq 0.99$ (underlined) and $\mathrm{P}<0.99$ (double underlined). NB: ns refers to not significant coefficients.

\begin{tabular}{lcccc}
\hline & \multicolumn{4}{c}{ Hg in mother } \\
$\begin{array}{c}\text { Hg in } \\
\text { fotus }\end{array}$ & $\begin{array}{c}\text { liver } \\
\text { (n=17) }\end{array}$ & $\begin{array}{c}\text { kidney } \\
(\mathrm{n}=17)\end{array}$ & $\begin{array}{c}\text { muscle } \\
(\mathrm{n}=16)\end{array}$ & $\begin{array}{c}\text { blood } \\
(\mathrm{n}=9)\end{array}$ \\
\cline { 3 - 5 } $\begin{array}{c}\text { liver } \\
\text { kidney }\end{array}$ & $\underline{\underline{0.650}}$ & $\underline{\underline{0.679}}$ & $\underline{\underline{0.641}}$ & $\mathrm{~ns}$ \\
\hline
\end{tabular}




\section{Figures}

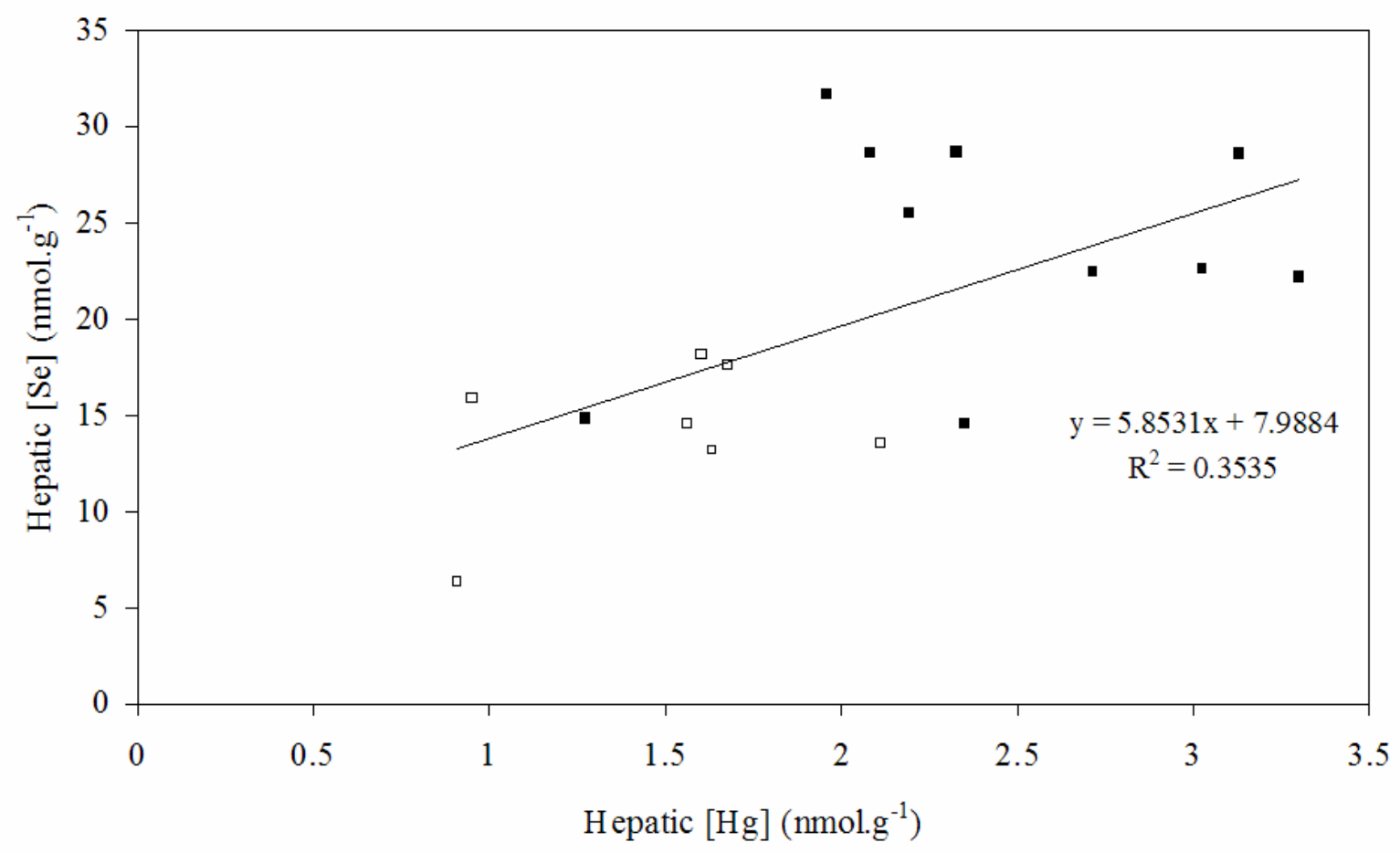

Figure 1. Relationships between $\mathrm{Hg}$ and Se molar levels (nmol.g ${ }^{-1}$ w.wt.) in the liver of common dolphin foetuses. Foetuses from the mass living stranding event are represented by black squares, and those from single stranding events by white squares. 


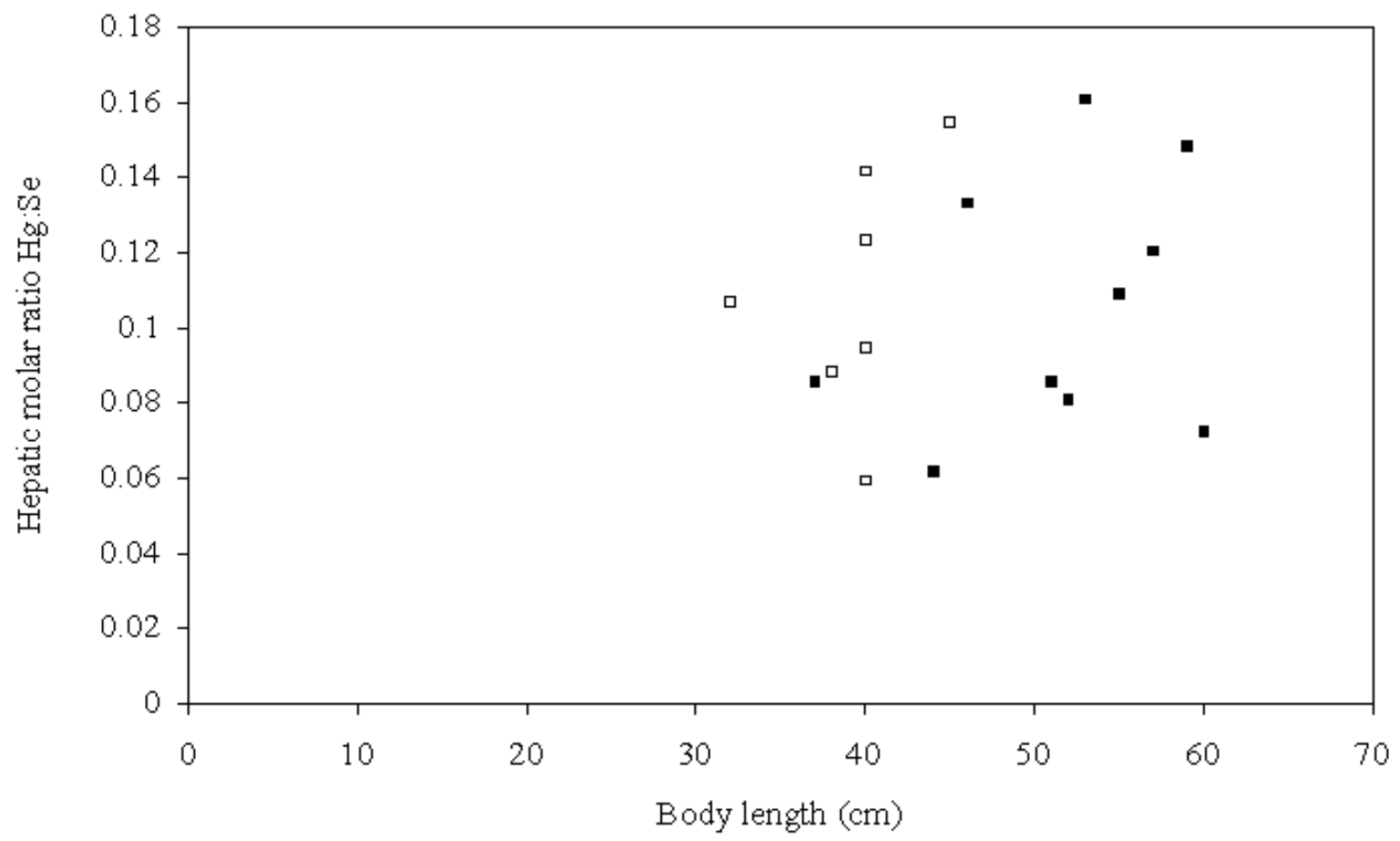

Figure 2. Relationships between hepatic molar ratio $\mathrm{Hg}: \mathrm{Se}$ and body length $(\mathrm{cm})$ in common dolphin foetuses. Foetuses from the mass living stranding event are represented by black squares, and those from single stranding events by white squares. 